\title{
Carbon Dioxide Adsorption on Activated Carbon Hydrothermally Treated and Impregnated with Metal Oxides
}

\author{
(Penyerapan Karbon Dioksida pada Karbon yang Diaktifkan Secara Rawatan Hidrotermal dan Impregnasi \\ dengan Logam Oksida) \\ Hazimah Madzaki, Wan Azlina Wan Ab Karim Ghani* and Thomas Choong Shean Yaw \\ Department of Chemical and Environmental Engineering, Faculty of Engineering, Universiti Putra Malaysia, Malaysia. \\ Sustainable process Engineering Research Centre, Universiti Putra Malaysia \\ Umer Rashid \\ Institute of Advance Technology (ITMA), Universiti Putra Malaysia, Selangor, Malaysia. \\ Noraziah Muda \\ TNB Research Sdn. Bhd., Selangor, Malaysia.
}

ABSTRACT

Activated carbon (AC) has been used widely as an agent for carbon dioxide ( $\left.\mathrm{CO}_{2}\right)$ adsorption due to its environmentally friendly nature, low cost, high porous structure, high surface area and good mechanical properties. Modifications have been made to AC in order to enhance its adsorptive properties. In this study, the performance of activated carbon modified by hydrothermal treatment and impregnation techniques was compared using metal oxides. The prepared samples were characterized by different techniques using X-ray diffraction (XRD) and scanning electron microscopy (SEM). The adsorption of $\mathrm{CO}_{2}$ was investigated using a $\mathrm{CO}_{2}$ adsorption unit, whereby $20 \%$ of $\mathrm{CO}_{2}$ gas was passed through the samples until a breakthrough point was achieved. During the adsorption study, it was found that AC that had been hydrothermally treated with cerium oxide $\left(\mathrm{CeO}_{2}\right)$ had the highest adsorption capacity of $0.856 \mathrm{mmol} / \mathrm{g}$ with a breakthrough time of $19.33 \mathrm{~min}$.

Keywords: Activated carbon; carbon dioxide; hydrothermal; impregnation; metal oxides

\section{ABSTRAK}

Karbon yang diaktifkan (AC) adalah agen penjerapan karbon dioksida ( $\mathrm{CO}_{2}$ ) yang telah digunakan secara meluas kerana bersifat mesra alam, kos rendah, struktur berliang yang banyak, permukaan yang luas dan sifat mekanik yang baik. Pengubahsuaian AC telah dilakukan untuk meningkatkan sifat-sifat penjerapannya. Dalam kajian ini, prestasi karbon yang diaktifkan yang diubahsuai menggunakan rawatan hidrotermal dan teknik impregnasi dengan logam oksida dibandingkan. Sampel yang disediakan dicirikan oleh teknik yang berbeza menggunakan Difraksi sinar-X (XRD) dan pengimbasan mikroscopik electron (SEM). Kajian penjerapan $\mathrm{CO}_{2}$ dilakukan menggunakan unit penjerapan $\mathrm{CO}_{2}$ dengan mengalirkan $20 \%$ gas $\mathrm{CO}_{2}$ melalui sampel sehingga titik terobosan dicapai. Melalui kajian penjerapan ini, didapati bahawa AC dirawat secara hidrotermal dengan cerium oksida $\left(\mathrm{CeO}_{2}\right)$ memberikan kapasiti penjerapan tertinggi iaitu $0.856 \mathrm{mmol} / \mathrm{g}$ dengan masa kejayaan 19.33 min.

Kata kunci: Karbon yang diaktifkan; karbon dioksida; hidrotermal; impregnasi; logam oksida

\section{INTRODUCTION}

Nowadays, the climate of the earth is changing continuously due to various factors. These include anthropogenic forcing which is human induced activity that leads to increasing of the concentration of greenhouse gases (GHG) into the atmosphere as well as increasing the earth temperature that leads to global warming. (MET 2009). Increasing of carbon dioxide $\left(\mathrm{CO}_{2}\right)$ emissions has cause interest in effort to introduce efficient and cost-effective technologies for capturing or reducing $\mathrm{CO}_{2}$ from large point sources like coal-fired power plant. One of the main technologies in reducing greenhouse gases is post-combustion capture of $\mathrm{CO}_{2}$ because it has the potential to be retrofitted to existing coal-fired power plant without requiring substantial changes to the combustion process (Thiruvenkatachari et al. 2015). Technologies such as membrane separation, the conventional temperature swing adsorption (TSA) or pressure swing adsorption (PSA) have been proposed to capture $\mathrm{CO}_{2}$ from the flue gases (Zhou et al. 2012). However, these technologies have some disadvantages. For membrane separation, multiple stages of separation or recycling is needed since it cannot always give high separation degrees which makes the cost of membranes reactor is high (Olajire, 2010). The disadvantage of TSA and PSA is high energy consumption since TSA required high regeneration time while PSA need cooling and drying system for the flue gas (Pires et al. 2011). 
Adsorption was considered as one of the most promising technologies in the commercial and industrial applications because of the low energy requirement, cost advantage, and ease of applicability over a relatively wide range of temperatures and pressures (Song 2006; Duffy et al. 2006; Thiruvenkatachari et al. 2009). Carbon capture by adsorption technology had drawn much research effort recently and had done lots of work to improve capture performance (Gibbins and Chalmers 2008; Lee and Park 2015). Activated carbon (AC) as an agent for adsorption has been used for many years in many field. Gas-phase adsorption by activated carbon is a separation process in which adsorbate molecules are transferred to the pore surface of solid activated carbon (Sumathi et al. 2010). AC is mainly amorphous material that has large surface area and pore volume.

Modification on adsorptive properties of AC can be done by using chemical and physical methods (Rashidi \& Yusup 2016). AC loaded with metal oxides from salts of zinc, copper and iron has been recently reported (Hosseini et al. 2015; Kim et al. 2010; Somy et al. 2009; Yong \& Mata 2001). Carbon sorbents loaded with copper oxide $(\mathrm{CuO})$ can increase the adsorption capacity of the acidic gas since $\mathrm{CuO}$ is an electon donor as reported by Fenrong et al. (2010) and Kim et al.(2010) which show that $\mathrm{AC}$ modified with $\mathrm{CuO}$ showed higher adsorption capacity than unmodified AC. The study by Hosseini et al. (2015) shows that co-impregnation of 2 metals which are copper $(\mathrm{Cu})$ and zinc $(\mathrm{Zn})$ can further enhance the $\mathrm{CO}_{2}$ adsorption by $49 \%$. Literatures show that hydrothermal treatment can improve the chemical characteristic of carbon materials (Jain et al. 2015; Liu et al. 2010; Ma et al. 2014). Skubiszewska-Zięba et al. (2011) reported that the fractions of mesopores of carbon sorbents increase from $30 \%$ to $60 \%$ after hydrothermal treatment. Hence, the present study aimed on the adsorption of $\mathrm{CO}_{2}$ on $\mathrm{AC}$ loaded with cerium oxide $\left(\mathrm{CeO}_{2}\right), \mathrm{CuO}$ and mixture of $\mathrm{CeO}_{2}$ and $\mathrm{CuO}$ using different modification methods; wet impregnation and hydrothermal treatment.

\section{MATERIALS AND METHODOLOGY}

A commercial AC was used as unmodified adsorbent. High purity commercial powder metal nitrates, copper nitrate $\left(\mathrm{Cu}\left(\mathrm{NO}_{3}\right)_{2} \cdot 3 \mathrm{H}_{2} \mathrm{O}\right)$ and cerium nitrate $\left(\mathrm{Ce}\left(\mathrm{NO}_{3}\right)_{3} \cdot 6 \mathrm{H}_{2} \mathrm{O}\right)$ were used as metal oxide precursor to modify AC.

\section{HYDROTHERMAL TREATMENT}

$\mathrm{AC}$ is treated with metal nitrate of an appropriate concentration to obtain around $10 \mathrm{wt} \%$ of metal content per gram of $\mathrm{AC}$ ( $10 \mathrm{~mL}$ of $10 \mathrm{wt} \%$ metal solution/g of PSAC). $200 \mathrm{~mL}$ of 10 $\mathrm{wt} \%$ metal solution $/ \mathrm{g}$ and $20 \mathrm{~g}$ of AC are mixed at $200^{\circ} \mathrm{C}$ in the autoclave for $20 \mathrm{~min}$ (Jain et al., 2015). The autoclave was then cooled to room temperature and the samples was collected and dry at $60^{\circ} \mathrm{C}$ for 24 hours. The sample was thencalcined at $450^{\circ} \mathrm{C}$ for 1 hour under the flow of nitrogen $\left(\mathrm{N}_{2}\right)$.

\section{WET IMPREGNATION}

AC was impregnated with metal nitrate of $10 \mathrm{wt} \%$ metals loading. During the impregnation, the solutions of metal nitrate were continuously mixed with AC for $5 \mathrm{~h}$. Then the samples were heated to $70^{\circ} \mathrm{C}$ while being constantly stirred until the liquid was totally evaporated. After that the samples were dried in an oven at $60^{\circ} \mathrm{C}$ for a period of $24 \mathrm{~h}$. Finally, the prepared samples were heat-treated at $450^{\circ} \mathrm{C}$ for 1 hour in the presence of nitrogen to form the reduced sorbents (Hosseini et al. 2015; Sumathi et al. 2010b). Table 1 shows the naming of the samples prepared by both methods. Set up of hydrothermal treatment and wet impregnation were shown in Figure 1.

TABLE 1.The naming of the samples

\begin{tabular}{lcc}
\hline $\begin{array}{l}\text { Metal loaded/ } \\
\text { Method }\end{array}$ & $\begin{array}{c}\text { Hydrothermal } \\
\text { treatment }\end{array}$ & Wet impregnation \\
\hline Copper, $\mathrm{Cu}$ & ACCu-HT & ACCu-WI \\
Cerium, $\mathrm{Ce}$ & ACCe-HT & ACCe-WI \\
$\mathrm{Ce}$ and $\mathrm{Cu}$ & ACCeCu-HT & ACCeCu-WI \\
\hline
\end{tabular}

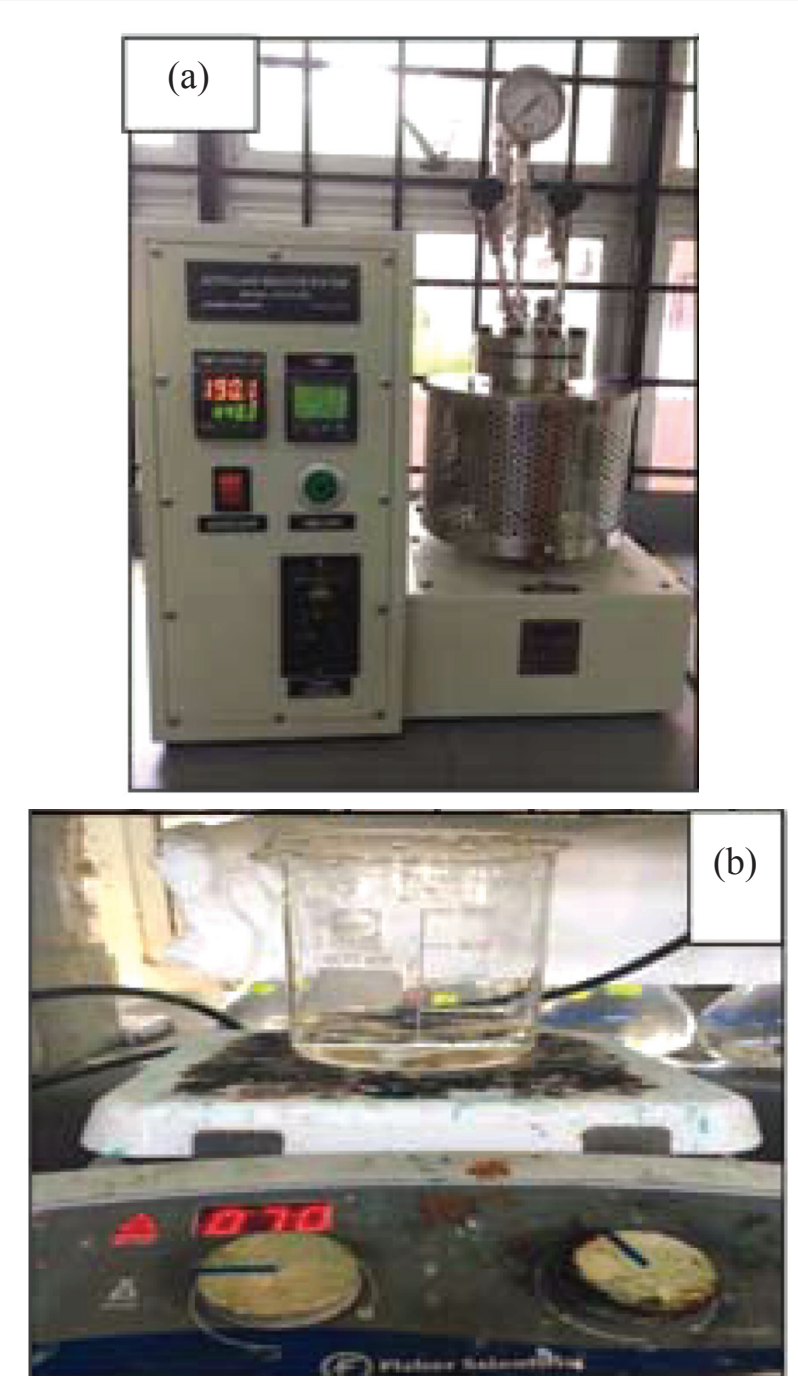

FIGURE 1. Set up of (a) hydrothermal treatment using autoclave reactor and (b) wet impregnation using hot stirring plate of $\mathrm{AC}$ 


\section{ADSORBENT CHARACTERIZATION}

The prepared samples were characterized by different techniques. The surface morphology of the samples is determined by Scanning Electron Microscopy (SEM). Determinations of the structure and fingerprint characterization of crystalline materials are done by using X-ray Diffraction (XRD).

\section{$\mathrm{CO}_{2}$ ADSORPTION TEST}

The adsorption of $\mathrm{CO}_{2}$ of the prepared sorbent was carried out in a $\mathrm{CO}_{2}$ adsorption unit shown in Figure $2.1 \mathrm{~g}$ of the sample was placed in the adsorption unit. A stream of gaseous mixture, containing $\mathrm{CO}_{2}$ and helium $(\mathrm{He})$, was passed through the prepared samples in the ration of 1:4. The reaction temperature of this process was preset to $30^{\circ} \mathrm{C}$. The outlet concentrations of $\mathrm{CO}_{2}$ were measured using a $\mathrm{CO}_{2}$ gas analyzer after sorption activity. The concentration of $\mathrm{CO}_{2}$ was recorded continuously for every $10 \mathrm{~s}$ until it reaches the breakthrough point. The activity of the sorbent towards $\mathrm{CO}_{2}$ is expressed by adsorption capacity, which is defined by the breakthrough curves $\left(\mathrm{C} / \mathrm{C}_{0}\right.$ versus $\left.\mathrm{t}\right) . \mathrm{C} / \mathrm{C}_{0}$ is a dimensionless factor, where $\mathrm{C}$ is the outlet concentration of (ppm) from the reactor, $\mathrm{C}_{0}$

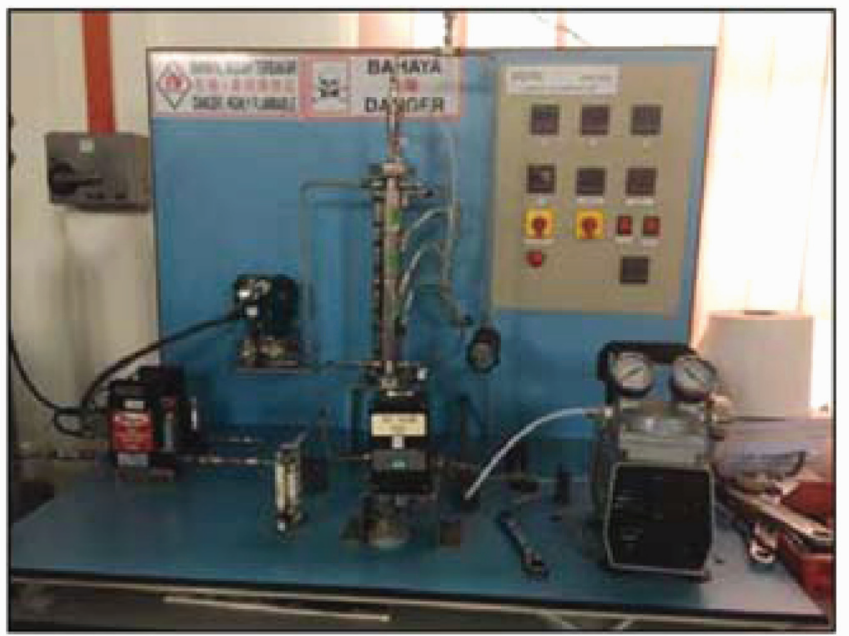

FIGURE 2. $\mathrm{CO}_{2}$ adsorption unit is the initial concentration (ppm) and $\mathrm{t}$ is the reaction time (min). Each and every experimental run was repeated at least three times to increase the precision of the results (Sumathi et al. 2010a).

\section{RESULTS AND DISCUSSION}

\section{CHARACTERIZATION OF MODIFIED SAMPLES}

The difference surface morphology of the raw and modified samples can be seen from the resultsof SEMimage shown in Figure 3 to 5. From Figure 3, it can be seen that the raw AC has high porosity with some impurities on it. After impregnation, from Figure 4 and 5, it can be seen that the metal particles have filled up some of the pores and covered the surface of $\mathrm{AC}$. Despite that, the adsorption of $\mathrm{CO}_{2}$ can still occur based on the reaction of the gas with metal oxides, not only on the surface and pores of the AC itself (Hidayu \& Muda 2016). The metal particles can be seen more uniformly dispersed on the AC surface by hydrothermal treatment compare to wet impregnation. This may happen as hydrothermal treatment is done under a controlled system compared to wet impregnation. Based on this observation, hydrothermally treated AC samples are assumed to give better adsorption performance.

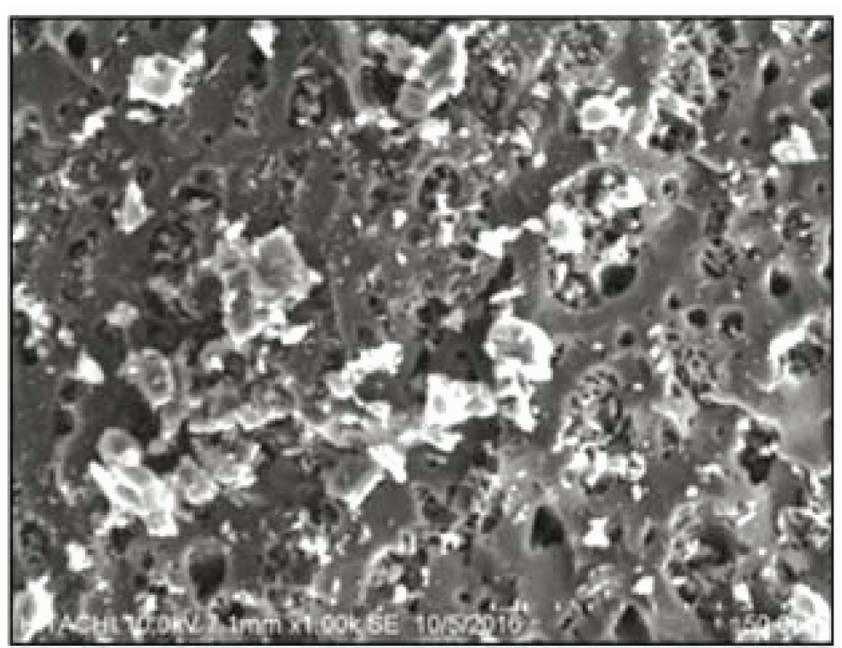

FIGURE 3.SEM image of raw AC

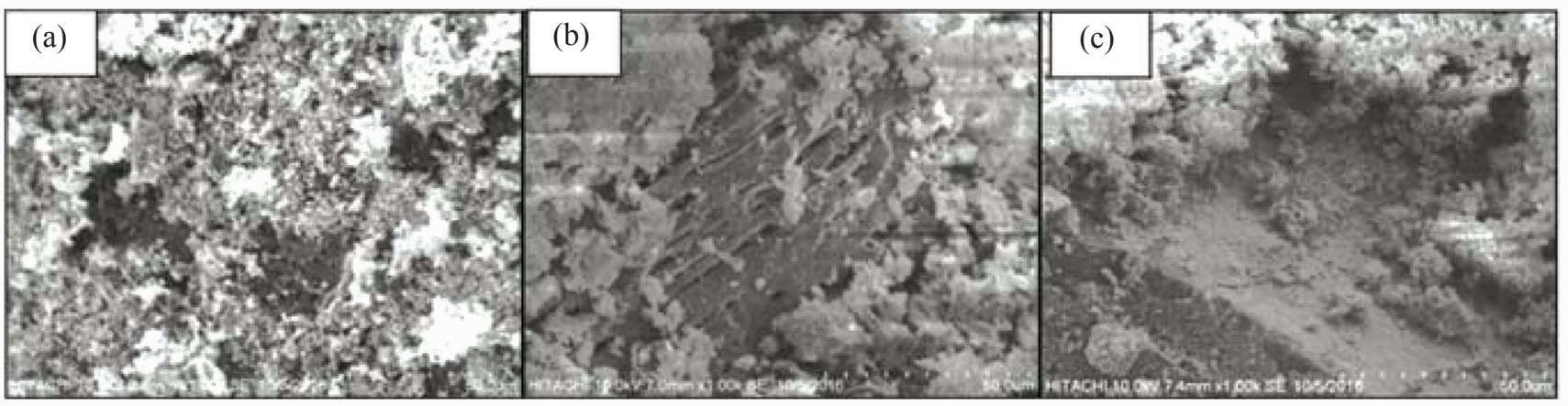

FIGURE 4. SEM images of impregnated AC. (a) ACCu-WI, (b) ACCe-WI and (c) ACCeCu-WI 


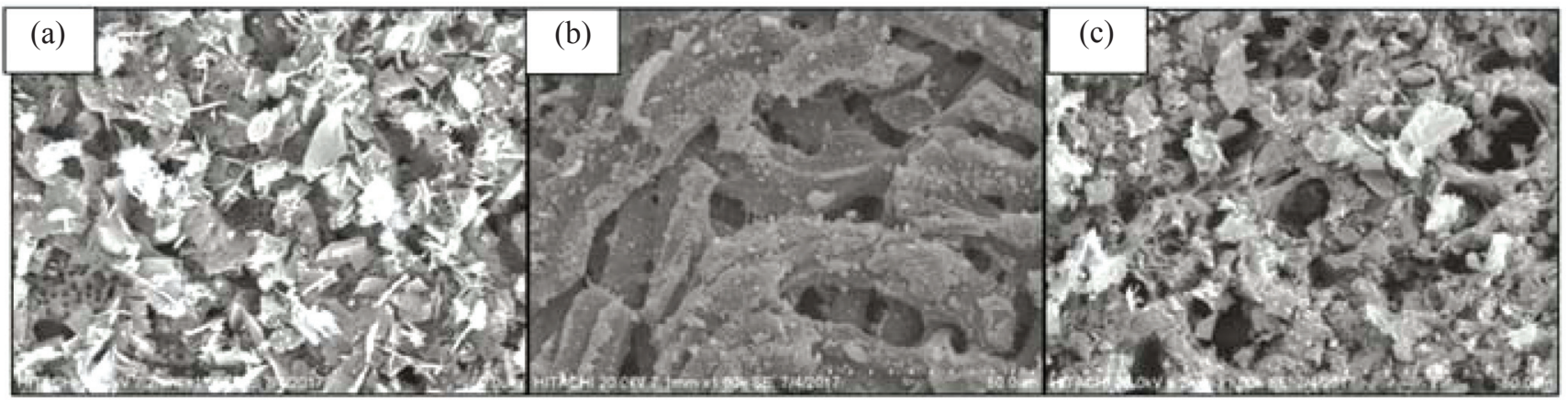

FIGURE 5. SEM images of hydrothermal treated AC. (a) ACCu-HT, (b) ACCe-HT and (c) ACCeCu-HT.

The XRD patterns for the modified AC are shown in Figure 6 . The figures show the comparison of the patterns for hydrothermal treated and impregnated AC. Based on the patterns, it can be seen that ACs that undergo hydrothermal treatment produce broader and higher peaks for all samples compared to impregnated AC. A broad peak at $2 \theta=20-30^{\circ}$ indicates the amorphous carbon structure. The broad carbon peak can be seen clearly for samples loaded with $\mathrm{CuO}$ (Figure 6 (a)) and can be seen a little for $\mathrm{CeO}_{2}$ loaded AC (Figure 6 (b)) but hardy seen in $\mathrm{AC}$ loaded with both $\mathrm{CeO}_{2}$ and $\mathrm{CuO}$ (Figure 6 (c)). This results correspond SEM analysis which shown that $\mathrm{AC}$ was mostly covered in $\mathrm{CeO}$ and $\mathrm{CuO}$ particles for $\mathrm{ACCeCu}$ sample. Figure 6 (c) also indicated that most peaks belong to $\mathrm{CeO}_{2}$ particle and only a few peaks belong to $\mathrm{CuO}$. This happened because the sample was first loaded with $\mathrm{Ce}$, then $\mathrm{Cu}$. The Ce particles may have taken up most of the area first. Based on the XRD pattern, it is found that the metal oxides particles are highly dispersed on the AC. On that account, it is expected that the adsorption efficiency can be improved due to the reaction that occurred between the metal oxides and $\mathrm{CO}_{2}$ (Hidayu \& Muda 2016). Based on the following equation:

$$
\mathrm{MO}+\mathrm{CO}_{2} \leftrightarrow \mathrm{MCO}_{3}
$$

where $\mathrm{M}$ is metal $(\mathrm{Cu}, \mathrm{Ce})$. It can be seen that 1 mole of metal oxide can chemically adsorb a stoichiometric equivalent of $\mathrm{CO}_{2}$ to form metal carbonate (Choi et al. 2009). Hence, the adsorption capacity is expected to be higher with the presence of metal oxides.

\section{$\mathrm{CO}_{2}$ ADSORPTION TEST}

The $\mathrm{CO}_{2}$ adsorption test was carried out using $\mathrm{CO}_{2}$ adsorption unit. The temperature was kept constant throughout the experiments at $30^{\circ} \mathrm{C}$. The samples were first flown through $\mathrm{He}$ to remove the $\mathrm{CO}_{2}$ present in the adsorption unit. Then, $20 \%$ of $\mathrm{CO}_{2}$ gas was flown through the sample for adsorption study. Figure 7 shows the comparison between the breakthrough curves of raw and modified AC as well as hydrothermal treated and impregnated AC.

Based on the breakthrough curves, it was found that ACCe-HT has the highest adsorption capacity which was 0.856 $\mathrm{mmol} / \mathrm{g}$. This high adsorption capacity may occur due to both physisorption and chemisorption based on the high surface area and highly dispersed metal. The breakthrough time for ACCe-HT was also high which is $19.33 \mathrm{~min}$. The longer the $\mathrm{CO}_{2}$ maintain in contact with the sorbents, the better the adsorption (Sumathi et al. 2010b). ACCeCu-WI has the lowest adsorption capacity and breakthrough time which were 0.117 $\mathrm{mmol} / \mathrm{g}$ and $9 \mathrm{~min}$ respectively. This may happened due to the low surface area of the sorbent. Since the metal oxides particles has filled up most of the pores and cover most of the AC surface, the adsorption occurred solely on chemisorption compared to other samples which both chemisorption and physisorption occur. The results of $\mathrm{CO}_{2}$ adsorption test for this study were presented in Table 2 as well as the adsorption studies by other literatures (Dinda 2013; González et al. 2013; Hosseini et al. 2015; Plaza et al. 2010; Ruiz et al. 2013; Thiruvenkatachari et al. 2013; Wang et al. 2011).

TABLE $2 . \mathrm{CO}_{2}$ adsorption test

\begin{tabular}{lccc}
\hline Sample & $\mathrm{q}(\mathrm{mmol} / \mathrm{g})$ & Breakthrough time $(\mathrm{min})$ & Source \\
\hline Raw AC & 0.652 & 19.17 & This Study \\
ACCu-HT & 0.585 & 18.17 & \\
ACCe-HT & 0.856 & 19.33 & \\
ACCeCu-HT & 0.560 & 15.33 & \\
ACCu-WI & 0.522 & 16.83 & \\
ACCe-WI & 0.117 & 10.17 & Plaza et al. 2010) \\
ACCeCu-WI & 0.056 & 17.00 & Wang et al. 2011 \\
AC & 0.77 & 14.00 & Dinda 2013 \\
Pitch sphere & 1.12 & 16.00 & Ruiz et al. 2013 \\
Alumina \& clay impregnated with $\mathrm{Na}_{2} \mathrm{CO}_{3}$ & 0.40 & - & González et al. 2013 \\
AC impregnated with $\mathrm{Na}{ }_{2} \mathrm{CO}$ & 0.09 & - & Thiruvenkatachari et al. 2013 \\
Biomass AC(olive stone (OS) \& almond & 1.1 & - & Hosseini et al. 2015 \\
shell $(\mathrm{AS})$ ) & 0.7 & 45.1 & \\
Carbon fibre composite & 2.65 & & \\
AC impregnated with $\mathrm{Cu}\left(\mathrm{NO}_{3}\right)_{2}$ & 2.26 & & \\
\& $\mathrm{ZnSO}_{4}$ & & & \\
\hline
\end{tabular}




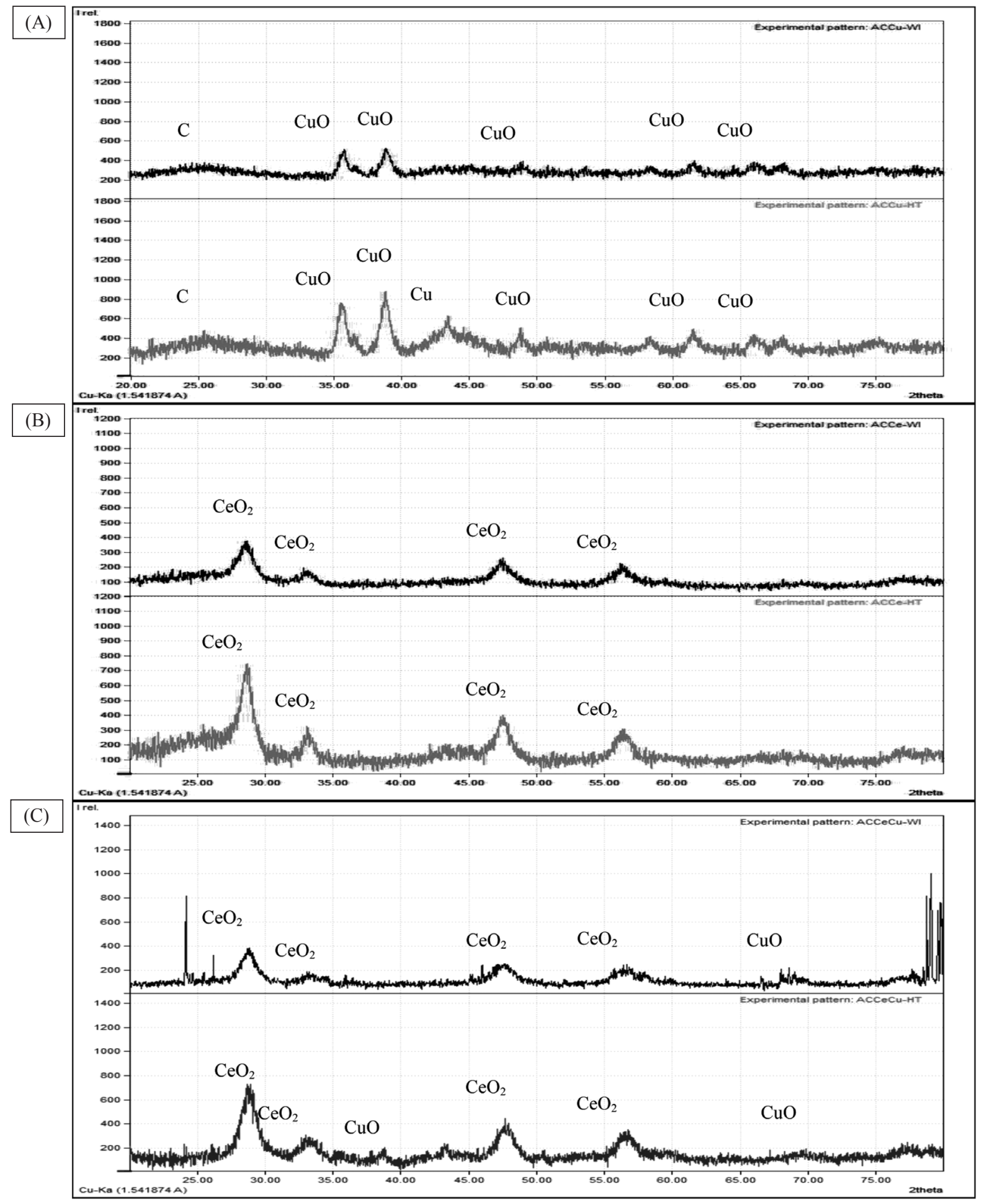

FIGURE 6. XRD patterns of modified $\mathrm{AC}$ (a) $\mathrm{CuO}$ loaded, (b) $\mathrm{CeO}_{2}$ loaded and (c) $\mathrm{CeO}_{2}$ and $\mathrm{CuO}$ loaded $\mathrm{AC}$ 


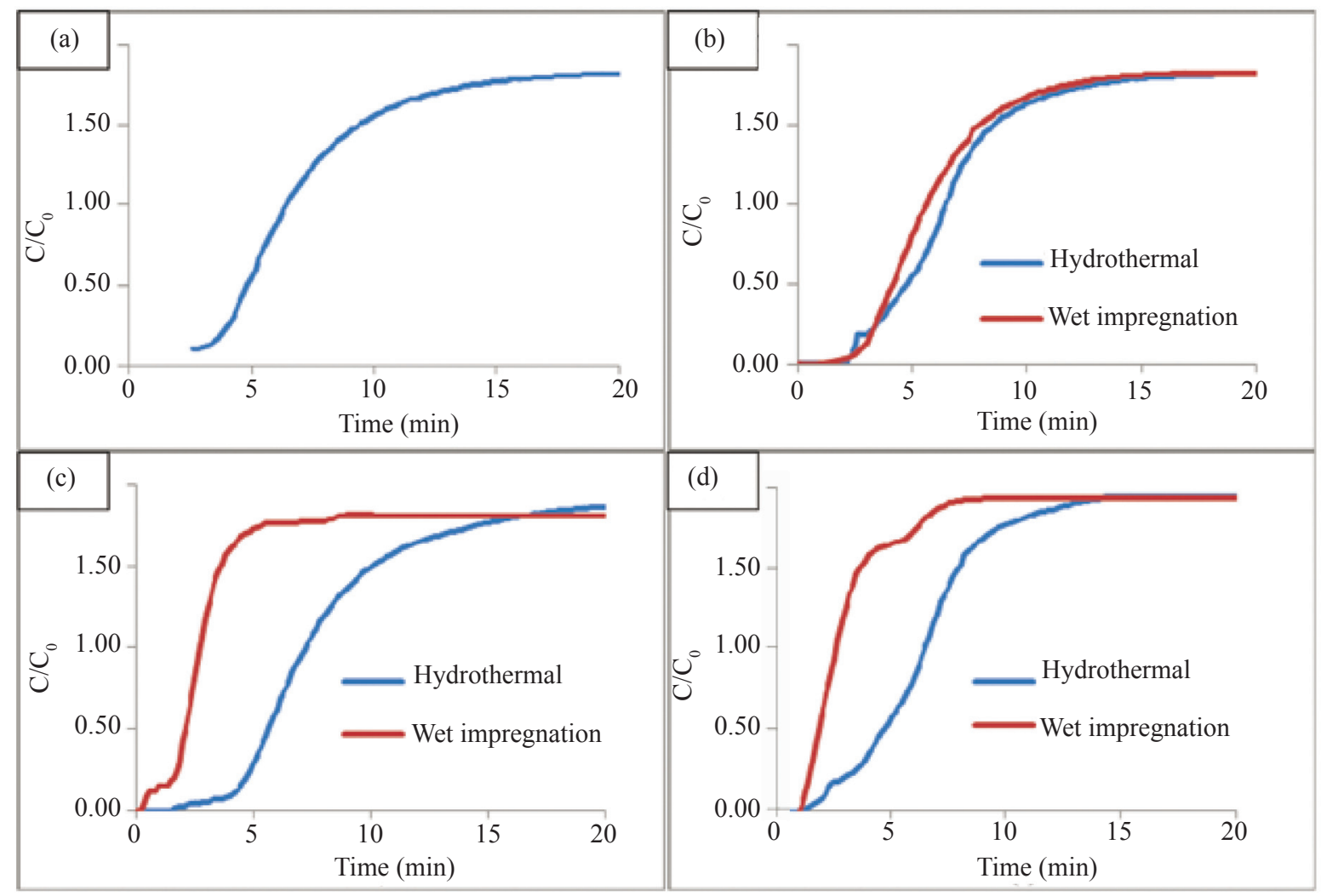

FIGURE 7. Breakthrough curve for (a) raw, (b) $\mathrm{CuO}$ loaded, (c) $\mathrm{CeO}_{2}$ loaded and (d) $\mathrm{CeO}_{2}$ and $\mathrm{CuO}$ loaded $\mathrm{AC}$

Based on the results from this study, it can be seen that the adsorption capacity and breakthrough time for AC hydrothermal treated are higher than the ones that are wet impregnated with metal oxides. The presence of metal on AC results in a basic surface that has strong affinity towards $\mathrm{CO}_{2}$ molecules and gives high adsorption capacity (Yong \& Mata 2001). However, it is important to choose the right method of introducing the metal oxide onto AC. Alvim-ferraz and Gaspar (2005) and Moradi (2014) stated in their study that impregnation of AC will cause deposition of metal compounds and blocks some of the pores that contributes in decreasing surface area and pore volume of AC. This statement coincides with the SEM results for wet impregnated ACs that are shown in Figure 4. The metal compounds deposit can be seen on some part of the AC surface and pores. This may have result in poor physic-sorption process and more of chemisorption process since most of the surface and pores are blocked by metals compound. The modification of AC using metal oxides by hydrothermal treatment is not yet explored. However, studies on hydrothermal treatment for other application like activation of chars and carbonation of biomass are widely reported (Jain et al. 2015; Liu et al. 2010; Ma et al. 2015; Skubiszewska-Zieba et al. 2011). Jain et al. (2015) has reported that coconut shells biomass which has high content of oxygenated functional group (OFG) were pre-treated with zinc chloride $\left(\mathrm{ZnCl}_{2}\right)$ or hydrogen peroxide $\left(\mathrm{H}_{2} \mathrm{O}_{2}\right)$ has increase the surface area and pore size of AC. It is believed that this also occurred in hydrothermal treated AC with metal oxides in this study since the pore size in SEM images appear bigger than the raw AC and impregnated AC.

\section{CONCLUSION}

The aim of the study is to determine the performance of modified AC using different techniques with metals oxides. The hydrothermal treated $\mathrm{AC}$ with $\mathrm{CeO}_{2}$ (ACCe-HT) shows higher adsorption capacity compared to raw AC which are 0.856 and $0.652 \mathrm{mmol} / \mathrm{g}$ respectively. All the other modified AC has lower adsorption capacity than the raw. The SEM and XRD patterns show that the $\mathrm{CeO}_{2}$ particles highly dispersed on the surface of AC as well as the pores. Hence, it is believed that both physisorption and chemisorption process involved in the adsorption of $\mathrm{CO}_{2}$ using ACCe-HT. This is highly associated with the large surface area and the reaction of metal oxides with $\mathrm{CO}_{2}$ molecules. The large surface area is most important in gas adsorption. Hydrothermal treatment provides better adsorption compare to wet impregnation due to the high OFG content that promotes higher surface area and pore sizes of the AC. Based on present work, it is believe that AC hydrothermally treated with metal oxides may be a promising adsorbent for $\mathrm{CO}_{2}$ capture. 


\section{ACKNOWLEDGEMENTS}

The authors express their gratitude to UPM/GP-IPB/9515201 for financial support. The help and assistance from various government and non-governmental organizations especially TNB Research is gratefully acknowledged. Apart from that we also would like to like to thank the Engineering and Physical Sciences Research Council for partial funding of this research through the BEFEW project (Grant No. EP/P018165/1)".

\section{REFERENCES}

Choi, S., Drese, J. H. \& Jones, C. W. 2009. Adsorbent materials for carbon dioxide capture from large anthropogenic point sources. ChemSusChem 2(9): 796-854.

Dinda, S. 2013. Development of solid adsorbent for carbon dioxide capture from flue gas. Separation and Purification Technology 109: 64-71.

Gibbins, J. \& Chalmers, H. 2008. Carbon capture and storage. Energy Policy 36(12): 4317-4322.

González, A. S., Plaza, M. G., Rubiera, F. \& Pevida, C. 2013. Sustainable biomass-based carbon adsorbents for post-combustion CO 2 capture. Chemical Engineering Journal 230: 456-465.

Hidayu, A. R. \& Muda, N. 2016. Preparation and characterization of impregnated activated carbon from palm kernel shell and coconut shell for $\mathrm{CO}_{2}$ capture. Procedia Engineering 148: 106-113.

Hosseini, S., Bayesti, I., Marahel, E. \& Eghbali, F. 2015. Adsorption of carbon dioxide using activated carbon impregnated with $\mathrm{Cu}$ promoted by zinc. Taiwan Institute of Chemical Engineers 52: 109-117.

Jain, A., Xu, C., Jayaraman, S., Balasubramanian, R., Lee, J. Y. \& Srinivasan, M. P. 2015. Mesoporous activated carbons with enhanced porosity by optimal hydrothermal pre-treatment of biomass for supercapacitor applications. Microporous and Mesoporous Materials, 218: 55-61.

Lee, S.Y. \& Park, S.J. 2015. A review on solid adsorbents for carbon dioxide capture. Journal of Industrial and Engineering Chemistry 23: 1-11.

Ma, Z., Chen, D., Gu, J., Bao, B. \& Zhang, Q. 2015. Determination of pyrolysis characteristics and kinetics of palm kernel shell using TGA - FTIR and model-free integral methods. Energy Conversion and Management 89: 251-259.

Ma, Z., Zhang, H., Yang, Z., Zhang, Y., Yu, B. \& Liu, Z. 2014. Highly mesoporous carbons derived from biomass feedstocks templated with eutectic salt $\mathrm{ZnCl}$ 2/KCl. Journal of Materials Chemistry A 2(45): 1932419329.

Olajire, A. A. 2010. $\mathrm{CO}_{2}$ capture and separation technologies for end-of-pipe applications - A review. Energy 35(6): 2610-2628.

Rashidi, N. A. \& Yusup, S. 2016. An overview of activated carbons utilization for the post-combustion carbon dioxide capture. Journal of $\mathrm{CO}_{2}$ Utilization 13: 1-16.
Ruiz, E., Sánchez, J. M., Maroño, M. \& Otero, J. 2013. CO capture from PCC power plants using solid sorbents: Bench scale study on synthetic gas. Fuel 114: 143152.

Skubiszewska-Zieba, J., Sydorchuk, V. V, Gun'ko, V. M. \& Leboda, R. 2011. Hydrothermal modification of carbon adsorbents. Adsorption 17(6): 919-927.

Somy, A., Mehrnia, M. R., Amrei, H. D., Ghanizadeh, A. \& Safari, M. 2009. Adsorption of carbon dioxide using impregnated activated carbon promoted by Zinc. International Journal of Greenhouse Gas Control 3(3): 249-254.

Thiruvenkatachari, R., Su, S., Yu, X. X. \& Bae, J. 2013. International Journal of Greenhouse Gas Control Application of carbon fibre composites to $\mathrm{CO}_{2}$ capture from flue gas. International Journal of Greenhouse Gas Control 13: 191-200.

Wang, Q., Luo, J., Zhong, Z. \& Borgna, A. 2011. CO 2 capture by solid adsorbents and their applications: current status and new trends. Energy \& Environmental Science 4(1): 42-55.

Yong, Z. O. U. \& Mata, V. G. 2001. Adsorption of carbon dioxide on chemically modified high surface area carbonbased adsorbents at high temperature, 41-50.

Alvim-ferraz, M. C. M. \& Gaspar, C. M. T. B. 2005. Impregnated active carbons to control atmospheric emissions: influence of impregnation methodology and raw material on the catalytic activity. Journal Environmental Science \& Technology 39(16): 62316236.

Fenrong, L. I., Honghong, Y. I., Xiaolong, T., Ping, N., Qiongfen, Y. U. \& Dongjuan, K. 2010. Adsorption of carbon dioxide by coconut activated carbon modified with $\mathrm{Cu} / \mathrm{Ce}$. Journal of Rare Earths 28(10): 334-337.

Kim, B., Cho, K. \& Park, S. 2010. Journal of Colloid and Interface Science Copper oxide-decorated porous carbons for carbon dioxide adsorption behaviors. Journal of Colloid And Interface Science 342(2): 575-578.

Liu, Z., Zhang, F. \& Wu, J. 2010. Characterization and application of chars produced from pinewood pyrolysis and hydrothermal treatment. Fuel 89(2): 510-514.

Moradi, S. E. 2014. Low-cost metal oxide activated carbon prepared and modified by microwave heating method for hydrogen storage. Journal of Chemical Engineering 31(9): 1651-1655.

Pires, J. C. M., Martins, F. G. \& Simões, M. 2011. Chemical engineering research and design recent developments on carbon capture and storage: An overview. Chemical Engineering Research and Design 89(9): 1446-1460.

Plaza, M. G., García, S., Rubiera, F., Pis, J. J. \& Pevida, C. 2010. Post-combustion CO2 capture with a commercial activated carbon: Comparison of different regeneration strategies. Chemical Engineering Journal 163(1-2): 41-47.

Sumathi, S., Bhatia, S., Lee, K. T. \& Mohamed, A. R. 2010a. Adsorption isotherm models and properties of $\mathrm{SO}_{2}$ and NO removal by palm shell activated carbon supported 
with cerium (Ce / PSAC). Chemical Engineering Journal 162(1): 194-200

Sumathi, S., Bhatia, S., Lee, K. T. \& Mohamed, A. R. 2010b. Performance of an activated carbon made from waste palm shell in simultaneous adsorption of SOx and NOx of flue gas at low temperature. Journal of Applied Science 10(12): 1052-1059.

Thiruvenkatachari, R., Su, S., Yu, X. X. \& Jin, Y. 2015. A site trial demonstration of $\mathrm{CO}_{2}$ capture from real flue gas by novel carbon fibre composite monolith adsorbents. International Journal of Greenhouse Gas Control 42: 415-423.

Wang, Z., Zhan, L., Ge, M., Xie, F., Wang, Y., Qiao, W., Ling, L. 2011. Pith based spherical activated carbon for $\mathrm{CO}_{2}$ removal from flue gases. Chemical Engineering Science 66(22): 5504-5511.

Zhou, X., Yi, H., Tang, X., Deng, H. \& Liu, H. 2012. Thermodynamics for the adsorption of $\mathrm{SO}_{2}, \mathrm{NO}$ and $\mathrm{CO}_{2}$ from flue gas on activated carbon fiber. Chemical Engineering Journal 200-202(2): 399-404.

Hazimah Madzaki, Wan Azlina Wan Ab Karim Ghani* and Thomas Choong Shean Yaw

Department of Chemical and Environmental Engineering, Faculty of Engineering,

Universiti Putra Malaysia,

43400 Serdang, Selangor, Malaysia.
Umer Rashid

Institute of Advance Technology (ITMA),

Universiti Putra Malaysia,

43400 Serdang, Selangor, Malaysia.

Noraziah Muda

TNB Research Sdn. Bhd.,

No. 1, Lorong Ayer Itam,

Kawasan Institusi Penyelidikan,

43000 Kajang, Selangor, Malaysia.

*Corresponding author; email: wanazlina@upm.edu.my

Received date : $17^{\text {th }}$ September 2017

Accepted date : $19^{\text {th }}$ January 2018

In Press date $: 1^{\text {st }}$ April 2018

Published date : $30^{\text {th }}$ April 2018 